\title{
Farm Producers' Household Consumption and Individual Risk Behavior after Natural Disasters
}

\author{
Ahmad Zia Wahdat ${ }^{1 \star(D), ~ M i c h a e l ~ A . ~ G u n d e r s o n ~}{ }^{2}$ and Jayson L. Lusk ${ }^{1}$ \\ ${ }^{1}$ Department of Agricultural Economics, Purdue University, West Lafayette, IN, USA and ${ }^{2}$ MetLife \\ Investment Management, Whippany, NJ, USA \\ ${ }^{*}$ Corresponding author. Email: awahdat@purdue.edu
}

(Received 8 September 2020; revised 21 December 2020; accepted 31 December 2020)

\begin{abstract}
Understanding how farm household consumption responds to adverse income shocks can provide insight into household well-being and appropriate agricultural policy. Using a split-sample survey of Indiana specialty producers, where we randomly assign respondents to treatments that vary the size of a hypothetical income shock, we estimate the relationship between income loss and household consumption. Given that postdisaster producers' risk preferences are important for business decisions, we elicit producers' risk preferences. We find that food and miscellaneous expenses are the most sensitive to income losses. We also find evidence for decreasing absolute risk aversion among producers after the income loss shock.
\end{abstract}

Keywords: consumption; natural disasters; resiliency; risk; specialty crops

\section{Introduction}

A prediction of the permanent income hypothesis is that households use savings in the event of an income shock to smooth consumption over their lifetimes. However, when households are lacking assets, it is likely that they have insufficient savings and face credit constraints, which render consumption smoothing almost impractical (Jappelli and Pistaferri 2010; Hallegatte et al. 2017). It becomes obvious that an income shock to a low-asset household would imply a reduction in consumption expenses. Whether a reduction in expenses is concentrated in one consumption category or multiple categories is an important and relevant question for household well-being after income shocks.

The objective of this study is twofold: first, to determine how farm households adjust consumption expenses after an unexpected income loss due to natural disasters, and second, to evaluate whether an income loss experience affects producers' risk-taking behavior. We further complement the analysis with a survey of producers' resilience capacity against natural disasters. We focus specifically on specialty crop farm households in the Midwestern state of Indiana. This is due to the fact that (i) specialty

(C) The Author(s) 2021. This is an Open Access article, distributed under the terms of the Creative Commons Attribution licence (http://creativecommons.org/licenses/by/4.0/), which permits unrestricted re-use, distribution, and reproduction in any medium, provided the original work is properly cited. 
crops in the Midwestern region are vulnerable to natural disasters, (ii) specialty crops' acres are the least covered by federal crop insurance, and (iii) Indiana specialty crop enterprises are mainly small in size and rely on family labor. In our results, we find that farm households reduce their monthly expenditures of food and miscellaneous categories by $\sim \$ 119$ and $\sim \$ 280$, respectively, after an income loss of 20-32 percent. $^{1} \mathrm{We}$ also find that producers are less willing to take financial risk after an income loss experience.

Our study contributes to the literature on agricultural vulnerability to climate change and weather shocks (Walthall et al. 2013; Kistner et al. 2018; Grabrucker and Grimm 2020). We estimate the potential impact of income loss due to natural disasters on Indiana specialty producers' household consumption expenses. Furthermore, our study contributes to the literature on producers' risk preferences in two areas: (i) We measure producers' risk preferences immediately after they experience natural disasters because it is an important time in terms of farm investment and household consumption decisions and (ii) we assess whether producers who receive a hypothetical negative income shock are more risk-averse than a counterfactual group of producers. These contributions relate to the literature on decreasing absolute risk aversion (Pratt 1964; Arrow 1971) and the nonstability of risk preferences over time (Malmendier and Nagel 2011; Guiso, Sapienza, and Zingales 2018).

Specialty crops' production in the Midwestern United States was worth $\$ 5.24$ billion in market value in 2017 (National Agricultural Statistics Service 2019c). ${ }^{2}$ These crops' yields are subject to weather and climate threats, which are projected to be intensified by wetter springs and drier summers in the future (Kistner et al. 2018). It is already the case that U.S. agricultural losses are primarily driven by weather and climate disasters, that is, floods, droughts, and severe freezes (Smith 2018). How well do producer households recover from a disaster depends on the recovery tools and mechanisms in place. Despite federal crop insurance being an important risk management tool for U.S. agricultural producers, specialty crops are among the least covered agricultural crops. Nationally, only 34 percent of eligible vegetable crops' acreage was enrolled in federal crop insurance programs in 2015 as compared to 89 percent of major crops, that is, corn, wheat, and soybean (Shields 2017). In the case of fruits and nuts, 74 percent of the acreage was insured, which is still much lower than that of major crops (Shields 2017). Moreover, the average total loss deductible for vegetables (35 percent) and fruits and nuts (41 percent) is higher than that for major crops (26 percent) (Shields 2017). ${ }^{3}$ Meanwhile, 86 percent of Indiana vegetable farms are classified as small and medium (less than $\$ 10,000$ and $\$ 250,000$ gross annual sales, respectively), and these farms mainly rely on family labor (Torres and Marshall 2016). Although farming is the primary occupation of around 41 percent of Indiana specialty producers (National Agricultural Statistics Service 2019a), the agricultural and asset losses from natural disasters can still have a deleterious effect on every farm household's income.

\footnotetext{
${ }^{1}$ Miscellaneous expenses include mortgage fees, charity, life insurance, and retirement expenses.

${ }^{2}$ The Midwest comprises the states of Illinois, Indiana, Iowa, Michigan, Minnesota, Missouri, Ohio, and Wisconsin. The figure $\$ 5.24$ billion is based on the following specialty crops: (i) vegetables, melons, potatoes, and sweet potatoes, (ii) fruits, tree nuts, and berries, and (iii) nursery, greenhouse, floriculture, and sod.

${ }^{3}$ Among vegetables, processing tomatoes' acreage is insured at a high rate of $94 \%$ (probably due to the presence of processor contracts). Producers might be able to purchase insurance coverage for noninsurable vegetable crops through the noninsured crop disaster assistance program (NAP) (Shields 2017).
} 
The consumption of low-income households is relatively more vulnerable to the negative effects of natural disasters than that of high-income households because lowincome households often lack the assets to protect them against natural disasters (Hallegatte et al. 2017). When a low-income household's consumption falls across food, health, and education categories, the household suffers a loss in well-being (Hallegatte et al. 2017). For instance, a consumption decline across food, health, and education categories can translate into poor health for household members or low employment prospects for their children in the future.

Given that farm producers' insurance, marketing, and commodity supply decisions partially depend on their risk-taking capacity (Chavas and Holt 1996; Eckman, Patrick, and Musser 1996; Zhao and Yue 2020), we investigate producers' risk preferences after a natural disaster and income loss experience. Understanding producers' consumption and risk behavior after a disaster can help with policies related to household recovery and designing credit and insurance instruments that can lessen the negative effects of natural disasters.

The study of consumption response and risk behavior after transitory income shocks is an active research area, although mired with data limitations (Attanasio and Weber 2010; Christelis et al. 2019). A natural disaster, or any income shock, happens at irregular intervals, while survey collections mostly happen at regular intervals, so aligning them together becomes difficult, particularly if interest is in measuring consumption and risk before and after a shock. To the best of our knowledge, we are the first to study farm household consumption responses to exogenous income shocks, where identification is clearly obtained by using an experimental design, albeit through a hypothetical survey. Our methods can be easily extended to other contexts to study producers' household and farm decisions.

\section{Literature Review}

Agricultural production activity is mired with risk due to price and production volatility, policies, institutional arrangements, and weather (Hardaker et al. 2004, pp. 1-4). In the case of rare "catastrophic" risks posed by natural weather events, producers lose crop production, which can directly affect their farm finances (Ogurtsov, Asseldonk, and Huirne 2008). Agricultural risk can affect farm output and finances, hence the reason that U.S. agricultural policy allocates considerable resources to farm risk management. In what follows, we discuss research related to agricultural losses due to natural disasters and their potential economic impacts. Next, we discuss the literature on farmers' and nonfarmers' risk preferences, which are sometimes measured in the aftermath of natural disasters.

Too little or too much of precipitation, compounded with erratic temperatures, can bring about drought, floods, and severe freezes. Such natural disasters pose substantial and perpetual threats to agricultural production. In the U.S., droughts inflicted $\$ 15$ billion in crop losses in 1988-1989 (Reibsame, Changnon, and Karl 1991), reduced corn and soybean yields by 0.1 percent to 1.2 percent per additional drought-week in 2001-2013 (Kuwayama et al. 2019), and inflicted losses of \$2 billion (crops) and \$553 million (dairy and livestock) in California in 2014-2016 (Howitt et al. 2014, 2015; Medellín-Azuara et al. 2016). The 1993 flooding in the Central United States caused $\$ 5$ billion in crop losses (Shannon and Motha 2015). In 2019, the flooding in Nebraska led to $\$ 440$ million in crop losses (Di Liberto 2019). Damaging freezes, which are common to the U.S. and Canada, have historically led to orange and citrus 
production losses in California and Florida; and crop and fruit damage in the Plains, the South, and the Midwest in 2007 (Shannon and Motha 2015). In 2020, the COVID-19 pandemic (if considered a natural disaster) severely affected the U.S. agricultural sector; it is estimated that the net farm income will decrease by about $\$ 20$ billion (Westhoff et al. 2020). The derecho of August 10, 2020, wreaked havoc on crops in Iowa and the U.S. Midwest-the estimated losses are projected to be about $\$ 4$ billion, thus making the 2020 derecho one of the costliest weather events of the past decade (Voiland 2020).

Although natural disasters are a threat to agricultural production, they have pushed U.S. farmers to adapt and consider new methods and strategies, for instance, the use of climate data in farm decision-making, participation in crop insurance programs, crop diversification, soil conservation, and livestock breed selection (Walthall et al. 2013). Adaptive strategies may protect farm production if there is climatic stability; however, the twenty-first century is predicted to have more variable climatic conditions (Walthall et al. 2013). Erratic weather and climate are specifically harmful to specialty crops, which are more sensitive to climatic stressors than row crops (Kistner et al. 2018). From 1989 to 2015, specialty crops in the Midwest have been constantly affected by weather hazards (Kistner et al. 2018). In 2007, California lost about 20 percent of orange production due to severe freeze (Shannon and Motha 2015).

Given that natural disasters affect specialty crops' production, the low insurance coverage of these crops poses a financial risk to specialty crop farms. Despite the availability of the Non-Insurance Assistance Program (NAP) under the Federal Crop Insurance Reform Act of 1994, research shows that specialty producers were not compensated well enough compared with ad hoc disaster payments in 1988-1993 (Lee, Harwood, and Somwaru 1997). The Whole Farm Revenue Protection (WFRP) insurance serves as an attractive risk management option for specialty crop producers due to its higher premium subsidy rates than other insurance policies; however, participation rates for WFRP remain low (for instance, 0.1 percent of all insurance policies in Indiana are WFRP) (Olen and $\mathrm{Wu} 2017$ ). The gist of the above literature points toward the increasing vulnerability of farms and farmer livelihoods to climate change, more so true for small family farms (Walthall et al. 2013).

The impact of natural disasters on farmers' income and consumption is well documented for developing countries, where farming is small scale, and livelihoods depend on agricultural production. For instance, natural disasters' effects have been studied for consumption (Townsend 1994; Morduch 1995; Kazianga and Udry 2006; Porter 2012), farm and livestock management (Rosenzweig and Binswanger 1993; Hoddinott 2006), and nutrition and health (Hoddinott 2006; Kazianga and Udry 2006). Results from a recent study on the effects of rainfall shocks in rural Thailand suggest that (i) the impact of weather-based agricultural shocks is larger than what the current literature suggests and (ii) agricultural shocks affect input availability and costs for farm and nonfarm enterprises, and consumption expenditures for farm households (Grabrucker and Grimm 2020). Our study contributes to the above strand of literature by estimating the potential impact of income loss due to natural disasters on Indiana specialty producers' consumption expenditures.

Given that farmers make decisions in risky environments, it is also important to understand their risk preferences, which affect business decisions regarding crop insurance, marketing, and commodity supply (Chavas and Holt 1996; Eckman, Patrick, and Musser 1996; Zhao and Yue 2020). Following are the two key findings in the literature on farmers' risk preferences: (i) farmers' risk preferences are not the same across studies; on average, farmers are risk-averse, and (ii) from a methodological perspective, 
farmers should be able to comprehend the risk elicitation task, which can be improved with a contextualized presentation of the elicitation task (Iyer et al. 2020). In terms of methodological developments in measuring farmers' risk preferences, the multi-item 5 -point scales and lottery-based choice tasks are the most widely used methods since 2010, especially in European studies (Iyer et al. 2020).

While there is a large economics literature on measuring risk preferences (see Starmer 2000; DellaVigna 2009; Barseghyan et al. 2018), there is comparatively less on exploring how risk preferences might respond to exogenous income shocks or catastrophic disasters. In this regard, Chuang and Schechter (2015) provide a literature review of risk preferences after natural disasters, where some studies find an increase in risk aversion after disasters (Cameron and Shah 2015), others find a reduction in risk aversion (Eckel, El-Gamal, and Wilson 2009), and some find no change in risk aversion (Becchetti, Castriota, and Conzo 2012). The diverging results on risk preferences after natural disasters are probably due to subtleties intrinsic to natural disasters, or it is possible that the experimental method in each study is contributing to the different results across studies (Chuang and Schechter 2015). By measuring producers' risk preferences immediately after they experience a hypothetical natural disaster, our study aims to contribute to the diverse findings on disasters' effect on risk preferences (Chuang and Schechter 2015).

\section{Conceptual Framework}

The decision-making units in our study are farm households. We are interested in investigating the effect of an unexpected income loss due to natural disasters on farm household consumption categories.

Chetty and Szeidl (2007) provide the theoretical framework and initial evidence that when income shocks are "small" (income loss of up to 33 percent), households make downward adjustment in the consumption expenditures of "adjustable" goods like food rather than "commitment" goods such as durables, which have adjustment costs associated with them. The authors show that less than 33 percent of U.S. households cut the expenditures of durables like apparel and furniture; however, about 42 percent and 49 percent of U.S households cut the expenditures of adjustable goods like food and entertainment, respectively.

Regarding the impact of income loss due to natural disasters on farm household consumption expenditures, our first hypothesis is as follows:

H1: After a farm household receives a small negative income shock due to natural disasters, it will reduce the consumption expenditures of adjustable goods such as food, education, transportation, clothing, utilities, and miscellaneous.

Under assumption 4 of Chetty and Szeidl (2007), the presence of commitments (like durables) in household consumption magnifies risk aversion with respect to wealth (income) in the (S,s) band (Chetty and Szeidl 2007). The (S,s) band is a rule where a household finds it optimal to hold onto a durable good as long as the after-shock income level is within an upper (S) and lower (s) band; however, when the after-shock income falls outside the $(\mathrm{S}, \mathrm{s})$ band, it is optimal to adjust the consumption of the durable good. For instance, if a household head gets unemployed and the income level falls below (s), then it would be optimal to move to a lower-rent house rather than reducing food and health consumption by a large amount. Chetty and Szeidl (2007) classify an 
income loss of up to 33 percent as a small income shock, which allows income to stay within the $(\mathrm{S}, \mathrm{s})$ band, hence allowing a household to only reduce the consumption of adjustable categories (Chetty and Szeidl 2007). This is true for the following two reasons: (i) the elasticity of adjustable goods with respect to income is higher in the presence of commitments than without commitments and (ii) the complementarity between adjustable and commitment goods magnifies risk aversion (Chetty and Szeidl 2007).

Our second objective is to estimate the impact of income loss on producers' risk behavior. Our second hypothesis is about the risk aversion of producers after receiving a negative income shock, that is,

H2: Producers that lose income after a natural disaster (treatment group) will be more risk averse compared to producers that do not lose income (control group).

The second hypothesis implies a decreasing absolute risk aversion. Arrow (1971) and Pratt (1964) argue that absolute risk aversion is decreasing in wealth (income). Also, numerous studies provide the evidence for decreasing absolute risk aversion, for instance, Binswanger (1980, 1981), Lins, Gabriel, and Sonka (1981), Hamal and Anderson (1982), Chavas and Holt (1996), Bar-Shira, Just, and Zilberman (1997), and Holt and Laury (2002).

\section{Survey Design}

In order to test the study hypotheses and to collect socioeconomic and farm operation data on Indiana specialty producers, we administered a survey in the second half of 2019. The survey had three major sections (see supplementary material for survey questionnaire). The first section pertains to assessing producers' resiliency in the face of natural disasters. The second section is about producers' income and consumption, that is, their average monthly income and itemized consumption expenditures in the last 12 months, and how consumption expenditures would change in the next 12 months for a given income loss due to a natural disaster. ${ }^{4}$ The third section pertains to eliciting producers' risk preferences.

In terms of sample selection, we first identified the population of Indiana specialty producers, which amounts to 2,301 producers based on the 2017 Census of Agriculture (National Agricultural Statistics Service 2019b). We created our survey sample by combining unique producers from five sources, that is, Farm Market ID, Indiana Horticultural Society (IHS), Indiana Vegetable Growers Association (IVGA), Indiana Grown-Indiana State Department of Agriculture (ISDA), and MarketMaker. We sent surveys to a total of 1,600 unique producers, which is about 70 percent of the population sample. We conducted the survey in three different phases, where each phase included an invitation letter, the survey itself, and a follow-up notification. In the first phase in July 2019, we sent mail surveys to a thousand unique specialty crop producers. In the second and third phases in August 2019 and November 2019, we sent online surveys to 400 and 200 unique specialty crop producers, respectively. The overall response rate was 6 percent (98 surveys) with 14 incomplete surveys that were discarded. The usable sample size of 84 remaining surveys yields a sampling error of \pm 10.5 percent for a binary question, with 95 percent confidence. Despite this wide

\footnotetext{
${ }^{4}$ The survey questionnaire includes modified questions on household and farm financials from the ARMS survey.
} 
confidence interval, as we soon discuss, we are mainly interested in making comparisons of individuals assigned to treatment and control groups, for which we have greater power to reject the null of no difference. It is also worth noting that although we only have a small share of producers represented in our survey (84 out of 2,301 ), we have a much larger share of specialty crop acres represented (5,432 acres out of 24,930 irrigated acres in the state).

Respondents were randomly assigned to either a treatment or a control group. The treatment variable is a hypothetical income loss shock. Also, the treatment group is made up of five subgroups. Each treatment subgroup differs from the others based on the size of the hypothetical income shock assigned. Households in each treatment subgroup receive an income loss shock of 20 percent, 24 percent, 26 percent, 30 percent, or 32 percent. ${ }^{5}$ The size of income shock to a household in the control group is only $\$ 120$, which is about 0.2 percent of income. Households' preshock income is calculated as the total after-tax income from farm and nonfarm sources in the last 12 months. The source of income loss for the treatment group is crop and house damage due to a natural disaster. The source of income loss for the control group is farm equipment damage due to a natural disaster.

Both the treatment and the control groups go through the hypothetical income loss intervention by observing pictures of flooding and crop freeze. The pictures do not change between these two groups. ${ }^{6}$ Treatment producers are told to imagine that due to the natural disasters as shown in the pictures, they suffer crop yield losses and home damage. Treatment producers are then told that these two types of damage reduce their average monthly income by 20-32 percent for the next 12 months. Control group producers are told to imagine that the natural disasters as shown in the pictures destroy parts of their town, and fortunately, they affect only some of their farm equipment that can be fixed with expenses of $\$ 120$. Hence, control group households' average monthly income in the next 12 months is lower by only a mere $\$ 10$. Itemized household-level expenditures are recorded before and after the income loss intervention. ${ }^{7}$ Income and consumption expenses are actual (hypothetical) in the preshock (postshock) period.

In order to let the household budget constraint bind in the postshock period, we control additional aspects in the household's economic environment like insurance coverage, borrowing limits, assets usage, and labor supply. Producers in the treatment group are told that their average monthly income drops by 20-32 percent in the next 12 months, including any partial amounts from their insurance coverage, loan application, and savings account. Finally, respondents are asked to assume that household labor in nonfarm jobs is held constant for the postshock 12 months, with no additional opportunities for extra hours of work.

In order to elicit the risk preferences of producers, first, we employ an 11-point Likert scale question as in Dohmen et al. (2011). We place this question before the hypothetical income loss exercise. Producers are asked, "Are you generally a person

\footnotetext{
${ }^{5}$ We provide variation in hypothetical income shock as a solution for netting out hypothetical bias in consumption responses.

${ }^{6}$ This makes sure that if there are any expenditure changes merely due to the pictures, it is accounted for both groups.

${ }^{7}$ If prices are constant, as would likely be the case with a localized weather shock, any changes in consumption expenditures translate into changes in consumption quantity for various household consumption categories.
} 
who is willing to take risks in financial matters or do you try to avoid taking risks in financial matters?" By ordering the 0-10-point Likert scale into intervals, our first method provides a measure of relative risk aversion as in Guiso, Sapienza, and Zingales (2018). Second, we present to the producers a series of hypothetical risky prospect choices as in Guiso, Sapienza, and Zingales (2018), which is similar to the Holt and Laury (2002) task. We present a risky lottery ( $\$ 10,000$ versus $\$ 0)$ with equal chances and then ask the producers whether they will choose the risky lottery or a certain amount, which keeps increasing, that is, $\$ 100, \$ 500$, etc. The second method is presented after the hypothetical income shock and provides us with a quantitative measure of absolute risk aversion. The second method is adjusted in wording to make it relevant for a producer's agribusiness context: "Imagine you are offered a farm investment opportunity, called the 'first opportunity,' that will pay you an annual net return of either $\$ 10,000$ or nothing $(\$ 0)$. The chances are half-and-half like a coin toss: $\$ 10,000$ when heads turn up and $\$ 0$ when tails turn up. Alternatively, you are offered a 'second opportunity' that has a fixed annual net return all the time. If the fixed annual net return is $\$ 100$, would you choose it instead of the first opportunity?"

\section{Descriptive Statistics}

Before presenting our empirical results regarding consumption and risk behavior, we discuss the descriptive statistics of producers' sociodemographics, farm operation, and resiliency. We also present covariates' balance between control and treatment samples. For sociodemographics and farm operation statistics, we also provide corresponding statistics from the USDA 2017 Census of Agriculture to get a sense of the representative nature of our sample. ${ }^{8}$

As presented in appendix Table A1, the overall sample is characterized by producers with a mean age of about 58 years, a household size of three members, and farm assets that are five times as large as household assets (approximately $\$ 2.5$ million versus $\$ 0.5$ million). Furthermore, about 80 percent of producers are male, 75 percent are married, and almost everyone classifies as White. More than half of producers and their wives have above high school education. A majority of producers work more than 50 percent of their time in farming, while their spouses do not. In comparison with our sample, USDA Indiana census is characterized by a slightly larger family size $(+1)$, a lower level of farm assets $(-\$ 0.5$ million), and a higher percentage of females (+10 percent). These slight differences might emerge because the census statistics represent all agricultural producers.

Moving to producers' farm operation statistics (appendix Table A2), the mean percentage of farm ownership is about 71 percent, which means that specialty producers in Indiana hold a majority of share in their farm operations. In our sample, the mean irrigated acreage of each vegetables and melons category $(\sim 60)$, fruits, nuts, and berries category $(\sim 8)$, and other crops category $(\sim 640)$ is bigger than the respective acreage of Indiana specialty producers in the USDA 2017 Census of Agriculture. This difference is most certainly due to a couple of producers in our sample with large-scale operations. The most prevalent legal status of operation is family- or individual-run business (more than 50 percent), followed by corporation (30.6 percent) and partnership ( 21 percent). In terms of the financial instrument that is available to run a farm operation, more than half of our sample producers select insurance, bank loan, personal savings, and credit card. This is in sharp contrast to government loan and relatives'

\footnotetext{
${ }^{8}$ In appendices Tables A1 and A2, the USDA census statistics are for all Indiana agricultural producers.
} 
Table 1. Treatment/Control Balance-Producer Demographics and Farm Operation Variables

\begin{tabular}{lccc} 
& \multicolumn{2}{c}{ Regression sample $(N=47)$} \\
\cline { 2 - 3 } & Treatment mean & Control mean & Norm. diff. score \\
\hline Respondent age & 57.37 & 63.17 & 0.41 \\
\hline Members Living in Household & 2.52 & 2.74 & 0.15 \\
\hline Gender (male $=1$ ) & 0.89 & 0.79 & 0.28 \\
\hline Married (yes $=1$ ) & 0.78 & 0.58 & 0.43 \\
\hline Race (white $=1$ ) & 0.96 & 0.94 & 0.08 \\
\hline Education (above high school =1) & 0.78 & 0.78 & 0.00 \\
\hline Occupation-majority time (farming $=1$ ) & 0.70 & 0.78 & 0.17 \\
\hline Farm assets (\$) & $2,898,269.23$ & $2,683,629.83$ & 0.04 \\
\hline Household assets (\$) & $562,288.46$ & $291,080.35$ & 0.56 \\
\hline Farm ownership percent & 62.56 & 73.84 & 0.29 \\
\hline Acres of vegetables and melons & 9.84 & 2.53 & 0.35 \\
\hline Acres of fruits, nuts, and berries & 4.04 & 4.33 & 0.01 \\
\hline Acres of other crops & 783.39 & 317.87 & 0.45 \\
\hline All variables (average) & & & 0.25 \\
\hline
\end{tabular}

Notes: Normalized difference scores are calculated based on the Imbens and Rubin (2015) method (please see the text for more discussion of this table and normalized scores). The mean of "Acres of Vegetables and Melons" in the treatment group is quite large compared with the control mean. This is due to a single producer in the treatment arm with a large number of vegetable and melon acres.

loan, which are selected by less than half of producers. Interestingly, about 8 percent of our sample producers consider none of the listed financial instruments as available to them.

When evaluating covariates' balance between treatment and control groups, we use the normalized differences method of Imbens and Rubin (2015), which is the difference in the mean covariate value between treatment and control groups, divided by the square root of the average of sample variances. A normalized score above 0.25 or 0.5 indicates a presence of distributional imbalance, which is concerning in the case of variables that are specifically relevant for the study (Imbens and Rubin 2015).

Using data from the regression sample, we present normalized difference scores for sociodemographic variables (Table 1). The regression sample includes only those respondents who fully answer the questions in the consumption and risk attitude sections. The average normalized difference score for all sociodemographic variables is 0.25 . Seven variables have normalized difference scores above 0.25 but not above 0.5 , representing a reasonable enough balance. The variable Household Assets has the highest score of 0.56; however, we would be more concerned if the variable Farm Assets had a score above 0.5 . The variable Farm Assets is directly relevant to farming and it is much larger in dollar value than Household Assets. The normalized difference score for Farm Assets is 0.04 .

In Table 2, we present average monthly income and consumption expenses by treatment and control households during the pre- and postshock periods. We observe that 
Table 2. Household Income and Consumption Expenses Before/After the Income Shock

\begin{tabular}{|c|c|c|c|c|}
\hline & \multicolumn{4}{|c|}{ Regression Sample $(N=47)$} \\
\hline & \multicolumn{2}{|c|}{ Preshock } & \multicolumn{2}{|c|}{ Postshock } \\
\hline & $\begin{array}{l}\text { Treatment } \\
\text { mean }(\$)\end{array}$ & $\begin{array}{l}\text { Control } \\
\text { mean }(\$)\end{array}$ & $\begin{array}{l}\text { Treatment } \\
\text { mean (\$) }\end{array}$ & $\begin{array}{l}\text { Control } \\
\text { mean }(\$)\end{array}$ \\
\hline \multicolumn{5}{|l|}{ Monthly } \\
\hline Income & $5,827.18$ & $5,422.37$ & $4,224.42$ & $5,412.37$ \\
\hline Health & 698.61 & 561.58 & 671.11 & 556.37 \\
\hline Rent & 53.57 & 41.32 & 62.50 & 38.68 \\
\hline Household furnishings & 68.79 & 70.79 & 22.32 & 55.37 \\
\hline Commitments category & 820.96 & 673.68 & 755.93 & 650.42 \\
\hline Food & 569.68 & 533.84 & 415.18 & 498.53 \\
\hline Education & 40.61 & 130.26 & 29.89 & 110.00 \\
\hline $\begin{array}{l}\text { Transportation (including gas } \\
\text { and maintenance) }\end{array}$ & 420.89 & 539.32 & 380.68 & 520.95 \\
\hline Entertainment & 124.71 & 183.89 & 46.57 & 134.16 \\
\hline Clothing and personal care & 117.61 & 142.05 & 57.61 & 118.58 \\
\hline Utilities & 329.46 & 399.84 & 221.25 & 394.58 \\
\hline Miscellaneous & $1,312.79$ & $1,260.63$ & $1,032.54$ & $1,260.11$ \\
\hline Adjustables category & $2,915.75$ & $3,189.84$ & $2,183.71$ & $3,036.89$ \\
\hline All consumption expenses & $3,672.43$ & $3,864.21$ & $2,745.00$ & $3,612.05$ \\
\hline Total observations & 28 & 19 & 28 & 19 \\
\hline
\end{tabular}

Notes: We follow the definition of Chetty and Szeidl (2007) for "commitments" and "adjustables" categories, and follow their Table 1 in identifying which expenses belong to each commitments and adjustables category. Expenses for health, rent, and furnishings belong to the commitments category, and the rest of the expenses belongs to the adjustables category. Since our definition of transportation includes gas and maintenance, and clothing includes personal care items, we assign these expenses to the adjustables category.

treatment (control) households' average monthly income reduces by about 28 percent ( 0.2 percent) after the shock, expenses for the commitments category reduce by 8 percent (4 percent), and expenses for the adjustables category reduce by 25 percent ( 5 percent). We clearly see that a large reduction in the treatment households' income is accompanied by a large reduction in their expenses for the adjustables category. We follow Table 1 of Chetty and Szeidl (2007) to identify if an expense belongs to the commitments category or to the adjustables category. Expenses for health, rent, and furnishings belong to the commitments category, and the rest of the expenses belong to the adjustables category. Since our definition of transportation includes gas and maintenance, and clothing includes personal care items, we assign these expenses to the adjustables category.

In appendix Table A3, we evaluate the distributional balance of income and consumption variables from the preshock period. The average normalized difference score for all variables in appendix Table A3 is 0.17 , and four variables have a score above 0.25 but below 0.5 , hence representing a good balance. In appendix Table A3, the last column 
presents each consumption category's mean share of income. Interestingly, adjustables' mean share of income is 64 percent, which is about four times larger than 18 percent of commitments. Also, the total consumption's mean share of income is 80 percent.

\section{Estimation Strategy}

Using data from the randomized survey of specialty producers in Indiana, we aim to empirically identify whether farm households reduce the consumption expenses of adjustable goods after the hypothetical income shock. Using panel data from the randomized survey, the empirical specification for testing hypothesis one is a differences-in-differences (DiD) regression model with household-fixed effects, that is,

$$
Y_{i j t}=\alpha+\rho_{i}+\gamma P_{t}+\delta\left(D_{j} \times P_{t}\right)+u_{i j t}
$$

where $Y_{i j t}$ represents the level of monthly expenditures as reported by household $i$ in treatment group $j$ at time period $t$. Additionally, $\rho_{i}$ is a household-specific intercept ("fixed effect"), capturing time-invariant household unobservable factors. $P_{t}$ is an indicator variable for the preshock $\left(P_{t}=0\right)$ and postshock $\left(P_{t}=1\right)$ periods. $\mathcal{D}_{j}$ is an indicator variable for the treatment $\left(\mathcal{D}_{j}=1\right)$ and control $\left(\mathcal{D}_{j}=0\right)$ groups. Our parameter of interest is $\delta$, which measures the average difference in expenditures between treatment and control households in the postshock period in comparison with the preshock period. Error terms are denoted by $u_{i j t}$. We use cluster-robust standard errors when estimating equation 1 . We cluster the error terms at the household level and assume error independence across households.

Regarding empirical testing of hypothesis 2, we follow the quantitative risk elicitation method of Guiso, Sapienza, and Zingales (2018). Hypothesis 2 states that producers who lose income after a natural disaster (treatment group) are more risk-averse than producers who do not lose income (control group). The quantitative risk elicitation method elicits producers' certainty equivalent in the face of a risky lottery $(\$ 10,000$ versus $\$ 0$ ) with equal chances. The certainty equivalent amount gradually increases as in the following sequence, so the producer may choose a given amount: $\$ 100, \$ 500$, $\$ 1,500, \$ 3,000, \$ 4,000, \$ 5,000, \$ 5,500, \$ 7,000, \$ 9,000$, and more than $\$ 9,000$. We then calculate the risk premium of each producer, which is the expected value of the risky lottery less the certainty equivalent, that is, $\$ 5,000-\mathrm{CE}$. The quantitative risk elicitation method provides us with a measure of absolute risk aversion. We use the interval regression method to model the risk premium $\left(r_{i}\right)$ of producer $i$ as

$$
r_{i}=\alpha+\delta D_{j}+\beta X_{i}+u_{i}
$$

where $\delta$ is our coefficient of interest which captures the average difference in risk premium between treatment and control producers. We also control for producers' sociodemographics and farm operation variables, $X_{i}$. We assume the error terms $u_{i}$ to be normally distributed.

\section{Results}

In Table 3, we present the main results on farm households' consumption behavior after the income shock. From left to right, we present results by (i) total consumption expenses, (ii) expenses for the commitments category, which includes health, rent, 
Table 3. Differences-in-Differences Regression-Household Consumption Expenses with Income Shock as a Treatment Variable

\begin{tabular}{|c|c|c|c|c|c|c|c|c|c|c|c|c|c|c|c|}
\hline & \multicolumn{15}{|c|}{ Regression sample } \\
\hline & Total & Commitments & Health & Rent & Furnishings & Adjustables & Food & Education & Transport & Entertainment & Clothings & Utilities & Misc. & $\begin{array}{l}\text { Commitments } \\
\text { share of } \\
\text { preshock } \\
\text { income }\end{array}$ & $\begin{array}{l}\text { Adjustables } \\
\text { share of } \\
\text { preshock } \\
\text { income }\end{array}$ \\
\hline \multirow[t]{2}{*}{ Treatment $\times$ postshock } & $-675.3^{\star \star}$ & -41.77 & -22.29 & 11.56 & -31.04 & $-579.1^{\star}$ & $-119.2^{\star}$ & 9.549 & -21.85 & -28.41 & -36.53 & -103.0 & $-279.7^{\star \star}$ & -0.0345 & $-0.187^{\star \star}$ \\
\hline & $(203.20)$ & $(66.48)$ & $(36.57)$ & (32.95) & $(19.25)$ & (226.25) & $(47.53)$ & $(21.60)$ & (60.89) & $(41.58)$ & $(28.82)$ & $(78.33)$ & $(92.84)$ & $(0.02)$ & $(0.06)$ \\
\hline \multicolumn{16}{|l|}{ Model evaluation } \\
\hline N & 94 & 94 & 94 & 94 & 94 & 94 & 94 & 94 & 94 & 94 & 94 & 94 & 94 & 94 & 94 \\
\hline Cluster groups & 47 & 47 & 47 & 47 & 47 & 47 & 47 & 47 & 47 & 47 & 47 & 47 & 47 & 47 & 47 \\
\hline $\mathrm{R}^{2}$ (within) & 0.49 & 0.04 & 0.02 & 0.00 & 0.20 & 0.30 & 0.31 & 0.05 & 0.02 & 0.19 & 0.17 & 0.07 & 0.27 & 0.10 & 0.35 \\
\hline F-statistic & 17.07 & 3.70 & 0.78 & 0.54 & 7.69 & 7.97 & 7.98 & 1.23 & 0.95 & 4.91 & 4.28 & 1.08 & 5.39 & 4.23 & 10.47 \\
\hline
\end{tabular}

Notes: In the above regression setup, there are two treatment groups, that is, treatment and control groups, and two periods that are separated by an income shock event, which happens at the

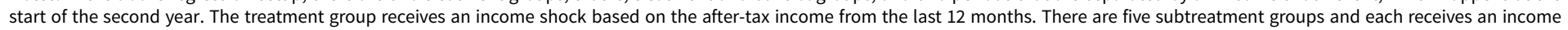
loss shock of 20 percent, 24 percent, 26 percent, 30 percent, or 32 percent. The five treatment groups are pooled together. We follow the definition of Chetty and Szeidl (2007) for "commitments" and "adjustables" categories, and follow their Table 1 in identifying which expenses belong to each commitments and adjustables category. Expenses for health, rent, and furnishings belong to the commitments category, and the rest of the expenses belongs to the adjustables category. Since our definition of transportation includes gas and maintenance, and clothing includes personal

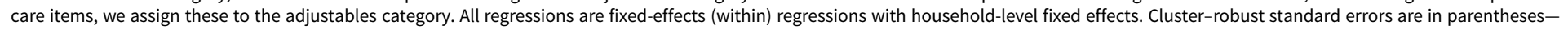
clustered at the household level. Significance level: ${ }^{*} p<0.05,{ }^{\star \star} p<0.01,{ }^{\star \star *} p<0.001$. 
and furnishings, and (iii) expenses for the adjustables category, which include expenses for food and every other expense up to miscellaneous. ${ }^{9}$ In a DiD specification with household-fixed effects, we identify whether a change in the average level of consumption expenses between preshock period and postshock period is statistically different between treatment and control households. We find a statistically significant reduction in the consumption expenses of treatment households for the following categories: (i) total consumption expenses $(\sim \$ 675)$ and (ii) expenses for the adjustables category $(\sim \$ 579)$ and its two subcategories that are food $(\sim \$ 119)$ and miscellaneous $(\sim 280)$. We find a statistically insignificant reduction in the consumption expenses of treatment households for the commitments category and its two subcategories (i.e., health and furnishings). Finally, we observe that treatment households increase the consumption expenses of rent and education; however, the changes are small and insignificant.

The above results are in conformity with the theoretical predictions of Chetty and Szeidl (2007), that is, after a small income shock, households reduce the consumption expenses of adjustable goods. We find evidence in support of our first hypothesis (H1) for the following expenses: all adjustable goods (a reduction of $\sim \$ 579$ ), food (a reduction of $\sim \$ 119$ ), and miscellaneous (a reduction of $\sim \$ 280$ ). However, we do not find evidence in support of our first hypothesis (H1) for the following expenses: education, transportation, clothing, and utilities. Two key takeaways from the consumption analysis of farm households in our sample are as follows: (i) a small income shock results in a downward adjustment of total consumption expenses, with the adjustment primarily concentrated in the adjustables category and (ii) within the adjustables category, a reduction in consumption expenses emanates from food and miscellaneous subcategories. In the last two columns of Table 3, we also show the regression results for commitments' and adjustables' share of preshock income. Among treatment households, on average, adjustables' share of income reduces by a significant 18.7 percent, which is in sharp contrast to the insignificant reduction of commitments' share of income (3.45 percent).

\section{Risk Behavior Before and After Income Shock}

Our risk elicitation method before the income loss intervention is based on an 11-point Likert scale method of Dohmen et al. (2011), while the risk elicitation method after the intervention is based on the risky lottery choice method of Guiso, Sapienza, and Zingales (2018). The former and the latter risk elicitation methods provide measures of "relative risk aversion" and "absolute risk aversion," respectively (Guiso, Sapienza, and Zingales 2018). ${ }^{10}$

Using an ordered logit specification for the relative risk aversion measure, we do not find any significant difference in risk-taking behavior between treatment and control producers (see Table 4). However, in an interval regression specification for the absolute risk-aversion measure, we find that, on average, the risk premium of treatment producers is about $\$ 2,307$ higher than that of control producers after the income loss intervention. Since an increase in risk premium translates into an increase in absolute risk aversion, we find the evidence in support of our second hypothesis (H2). We also confirm that absolute risk aversion is decreasing in wealth (income) as argued by Arrow (1971) and Pratt (1964).

\footnotetext{
${ }^{9}$ Miscellaneous consumption expenses include mortgage fees, charity, life insurance, and retirement expenses.

${ }^{10}$ The reason that we do not use the same risk elicitation method before and after the income loss intervention is to avoid the preintervention method potentially biasing the postintervention risky choices.
} 
Table 4. Producers' Risk Aversion Before/After the Income Shock

\begin{tabular}{|c|c|c|c|}
\hline & \multicolumn{2}{|c|}{ Preshock qualitative risk } & \multirow{2}{*}{$\begin{array}{c}\text { Postshock } \\
\text { quantitative risk } \\
\text { Risk premium in } \\
\text { dollars }\end{array}$} \\
\hline & $\begin{array}{l}\text { 11-Point risk } \\
\text { aversion }\end{array}$ & $\begin{array}{l}\text { 11-Point risk } \\
\text { aversion }\end{array}$ & \\
\hline & $\beta / S E$ & Odds ratio/SE & $\beta / S E$ \\
\hline Treatment & $\begin{array}{c}-0.932 \\
(0.64)\end{array}$ & $\begin{array}{l}0.394 \\
(0.25)\end{array}$ & $\begin{array}{l}2,307.0^{\star} \\
(966.51)\end{array}$ \\
\hline Male & $\begin{array}{c}0.564 \\
(1.18)\end{array}$ & $\begin{array}{l}1.758 \\
(2.08)\end{array}$ & $\begin{array}{c}-697.2 \\
(1,731.35)\end{array}$ \\
\hline Married & $\begin{array}{c}-0.101 \\
(0.96)\end{array}$ & $\begin{array}{l}0.904 \\
(0.87)\end{array}$ & $\begin{array}{c}-1,407.3 \\
(1,257.36)\end{array}$ \\
\hline Age & $\begin{array}{c}-0.0153 \\
(0.03)\end{array}$ & $\begin{array}{l}0.985 \\
(0.03)\end{array}$ & $\begin{array}{c}68.73 \\
(48.40)\end{array}$ \\
\hline Household members & $\begin{array}{c}-0.113 \\
(0.40)\end{array}$ & $\begin{array}{l}0.893 \\
(0.36)\end{array}$ & $\begin{array}{l}787.7 \\
(454.43)\end{array}$ \\
\hline Total acres & $\begin{array}{l}-0.0000437 \\
(0.00)\end{array}$ & $\begin{array}{l}1.000 \\
(0.00)\end{array}$ & $\begin{array}{c}-0.318 \\
(0.25)\end{array}$ \\
\hline Total assets (divided by $\$ 100,000$ ) & $\begin{array}{l}-0.00480 \\
(0.01)\end{array}$ & $\begin{array}{l}0.995 \\
(0.00)\end{array}$ & $\begin{array}{c}-5.317 \\
(7.24)\end{array}$ \\
\hline \multicolumn{4}{|l|}{ Model evaluation } \\
\hline Total observations & 40 & 40 & 40 \\
\hline Log likelihood & -52.79 & -52.79 & -76.65 \\
\hline$\chi^{2}$ & 2.81 & 2.81 & 9.87 \\
\hline$p>\chi^{2}$ & 0.90 & 0.90 & 0.20 \\
\hline
\end{tabular}

Notes: As discussed in the text, the qualitative risk measure elicits producers' willingness to take risk in the financial domain, following the Dohmen et al. (2011) method. It is referred to as the measure of relative risk aversion in Guiso, Sapienza, and Zingales (2018), and we model it using an ordered logit specification. The quantitative risk measure elicits producers' certainty equivalent in the face of a risky lottery $(\$ 10,000$ versus $\$ 0)$ with equal chances. The quantitative risk measure is referred to as the absolute risk aversion measure in Guiso, Sapienza, and Zingales (2018). We then calculate the risk premium of each producer, which is the expected value of the lottery less certainty equivalent amount $(\$ 5,000-$ $\mathrm{CE}$ ). We use the interval regression method to model the risk premium of producers. The qualitative risk measure is presented at the beginning of the survey (before income shock), and the quantitative measure is presented toward the end of the survey, after the shock. We dropped four observations because of inconsistency in response to risk questions. Two producers selected five or less (i.e., risk-averse) on the Likert scale for the qualitative measure, but they are extremely risk lovers after the shock (having a risk premium of $-4,000$ or less). Two other producers started as high risk takers (choosing 9 and 10 on the Likert scale), which dropped by two points each when asked the same question after the shock; however, their choice of risk premium $(-4,000$ or less) shows no indication of drop in risk taking. Robust standard errors are in parentheses. Significance level: ${ }^{\star} p<0.05,{ }^{\star \star} p<0.01,{ }^{\star \star \star} p<0.001$.

\section{Discussion of Results}

During the summer of 2019, when we started implementing the survey, the emotional state of Indiana farmers was mired with frustration due to the concurrent rainfalls, which postponed the growing season. The flooding in some Midwestern states like Nebraska cost many farm producers their year-long farm yields. Such erratic weather outcomes are to be expected due to climate change (IPCC 2018). In the agriculture sector, farm producers are the most vulnerable to the adverse effects of natural disasters. 
After a disaster's negative income shock, the impact on producers' household consumption and individual risk behavior cannot be discounted.

Due to a disaster's hypothetical income loss, the treatment producers in our study reduced their food and miscellaneous expenses by about $\$ 119$ and $\$ 280$, respectively. Each of these two downward adjustments is equal to $\sim 21$ percent of the expenses for the food and miscellaneous categories before the income loss, respectively. It is easy to adjust food and miscellaneous expenses during hard times, but they can have real consequences over producers' life. Meanwhile, a postdisaster increase in risk aversion can have implications for specialty producers' financial decisions. For instance, postdisaster farm investment can be critical for farm output and revenues, but an increase in producers' risk aversion would mean that they are not willing enough to take on farm investment.

In our study, we find that Indiana specialty producers have a moderate resiliency against natural disasters. When we compare the consumption and risk-taking findings in our study against the moderate resiliency of specialty producers in our study, it becomes clear that the producer households and their farm enterprises are vulnerable to natural disasters. On average, 42 percent of the total planted acres in our survey sample are insured, which is not quite high enough (appendix Table A4). We also learn that about 80 percent of producers' farms have been affected by extreme events at some point, but only 53 percent of producers engage in farm financial planning for worst times such as farm losses due to a natural disaster (appendix Table A4). Potential solutions for improving the resilience capacity of Indiana specialty producers could include (i) connecting producers with digital technologies to help them in predicting weather and climate risks and (ii) educating producers about farm risk management tools that could help them to proactively manage their farms.

\section{Conclusion}

Specialty crops play a vital role in the U.S. farm sector due to their contribution to farm income and U.S. households' nutrition. However, specialty crops' production involves more risk than commodity crops' production due to adverse weather shocks, specialty crops' low insurance coverage and low participation rates, labor shortages, and perishability of fresh produce. Also, it is mainly the small- and medium-sized producers who are easily exposed to the aforementioned risks and challenges. The objective of this study is twofold: first, to determine how specialty producers' household consumption responds to adverse income shock due to natural disasters, and second, to evaluate whether an income loss experience affects specialty producers' risk-taking behavior.

In this study, we focus on specialty producers in the Midwestern state of Indiana. We administered a split-sample survey in the second half of 2019, where we randomly assigned producers to treatments that vary the size of a hypothetical income shock due to natural disasters. We collected information on (i) producers' resiliency in the face of natural disasters, (ii) households' monthly consumption expenditures before and after an income loss of 20-32 percent due to natural disasters, and (iii) producers' risk preferences.

We find that farm households in our sample reduce their monthly expenses of food and miscellaneous categories by $\sim \$ 119$ and $\sim \$ 280$, respectively, after an income loss of 20-32 percent. We also find that our sample producers are less willing to take financial risks after an income loss experience, that is, they have decreasing absolute risk aversion. Finally, we find in our data that Indiana specialty producers have a moderate resilience 
capacity to withstand the adverse effects of natural disasters. Although specialty crops' production is risky and challenging, the good news is that specialty producers can become resilient and manage farm risk with sufficient knowledge and resources. We believe Indiana specialty producers would benefit from (i) farm financial planning for the worst times, (ii) immediate access to federal aid and commercial loans after natural disasters, (iii) high participation rate in federal crop insurance, (iv) investment in agriculture-related digital technologies, and (v) more research on vulnerability and adaptive capacity of specialty producers.

Supplementary material. The supplementary material for this article can be found at https://doi.org/10. 1017/age.2021.2.

Data Availability Statement. Survey instruments are available through the supplementary materials section of the article.

\section{References}

Arrow, K.J. 1971. Essays in the Theory of Risk-Bearing. Chicago, IL: Markham Pub. Co.

Attanasio, O.P., and G. Weber. 2010. "Consumption and Saving: Models of Intertemporal Allocation and Their Implications for Public Policy." Journal of Economic Literature 48(3): 693-751.

Bar-Shira, Z., R.E. Just, and D. Zilberman. 1997. "Estimation of Farmers' Risk Attitude: An Econometric Approach." Agricultural Economics 17(2-3): 211-222.

Barseghyan, L., F. Molinari, T. O'Donoghue, and J.C. Teitelbaum. 2018. "Estimating Risk Preferences in the Field." Journal of Economic Literature 56(2): 501-564.

Becchetti, L., S. Castriota, and P. Conzo. 2012. "Calamity, Aid and Indirect Reciprocity: The Long Run Impact of Tsunami on Altruism." Working Paper No. 316, Centre for Studies in Economics and Finance (CSEF), University of Naples, Italy.

Binswanger, H.P. 1980. "Attitudes Toward Risk: Experimental Measurement in Rural India." American Journal of Agricultural Economics 62(3): 395-407.

Binswanger, H.P. 1981. "Attitudes Toward Risk: Theoretical Implications of an Experiment in Rural India.” Economic Journal 91(364): 867-890.

Cameron, L., and M. Shah. 2015. "Risk-Taking Behavior in the Wake of Natural Disasters." The Journal of Human Resources 50(2): 484-515.

Chavas, J.P., and M. Holt. 1996. "Economic Behavior Under Uncertainty: A Joint Analysis of Risk Preferences and Technology." The Review of Economics and Statistics 78(2): 329-335.

Chetty, R., and A. Szeidl. 2007. "Consumption Commitments and Risk Preferences." The Quarterly Journal of Economics 122(2): 831-877.

Christelis, D., D. Georgarakos, T. Jappelli, L. Pistaferri, and M. van Rooij. 2019. "Asymmetric Consumption Effects of Transitory Income Shocks." The Economic Journal 129(622): 2322-2341.

Chuang, Y., and L. Schechter. 2015. "Stability of Experimental and Survey Measures of Risk, Time, and Social Preferences: A Review and Some New Results." Journal of Development Economics 117(C): 151-170.

DellaVigna, S. 2009. "Psychology and Economics: Evidence from the Field." Journal of Economic Literature 47(2): 315-372.

Di Liberto, T. 2019. River Flooding Inundates the Northern Plains in Spring 2019. NOAA Climate.gov. Available at: https://www.climate.gov/news-features/event-tracker/river-flooding-inundates-northernplains-spring-2019 (accessed April 2019).

Dohmen, T., A. Falk, D. Huffman, U. Sunde, J. Schupp, and G.G. Wagner. 2011. "Individual Risk Attitudes: Measurement, Determinants, and Behavioral Consequences." Journal of the European Economic Association 9(3): 522-550.

Eckel, C.C., M.A. El-Gamal, and R.K. Wilson. 2009. "Risk Loving After the Storm: A Bayesian-Network Study of Hurricane Katrina Evacuees." Journal of Economic Behavior and Organization 69(2): 110-124.

Eckman, D.T., G.F. Patrick, and W.N. Musser. 1996. "Factors Affecting Written Marketing Plan Adoption by Large-Scale Grain Producers.” Review of Agricultural Economics 18(4): 565-574. 
Grabrucker, K., and M. Grimm. 2020. "Is There a Rainbow after the Rain? How do Agricultural Shocks Affect Non-Farm Enterprises? Evidence from Thailand." American Journal of Agricultural Economics 125, DOI:10.1111/ajae.12174.

Guiso, L., P. Sapienza, and L. Zingales. 2018. “Time Varying Risk Aversion." Journal of Financial Economics 128(3): 403-421.

Hallegatte, S., A. Vogt-Schilb, M. Bangalore, and J. Rozenberg. 2017. Unbreakable: Building Poor People's Resilience in the Face of Disaster. Climate Change and Development Series, World Bank Group.

Hamal, K.B., and J.R. Anderson. 1982. "A Note on Decreasing Absolute Risk Aversion Among Farmers in Nepal." Australian Journal of Agricultural Economics 26(3): 220-225.

Hardaker, J.B., R.B.M. Huirne, J.R. Anderson, and G. Lien. 2004. Coping with Risk in Agriculture, 2nd Edition. Wallingford: CABI.

Hoddinott, J. 2006. "Shocks and Their Consequences Across and Within Households in Rural Zimbabwe." The Journal of Development Studies 42(2): 301-321.

Holt, C.A., and S.K. Laury. 2002. "Risk Aversion and Incentive Effects." American Economic Review 92(5): 1644-1655.

Howitt, R., J. Medellín-Azuara, D. MacEwan, J. Lund, and D. Sumner. 2014. "Economic Analysis of the 2014 Drought for California Agriculture." Working Paper, Center for Watershed Sciences, University of California Davis, Davis, CA.

Howitt, R., J. Medellín-Azuara, D. MacEwan, J. Lund, and D. Sumner. 2015. "Economic Analysis of the 2015 Drought for California Agriculture." Working Paper, Center for Watershed Sciences, University of California Davis, Davis, CA.

Imbens, G., and D.B. Rubin. 2015. Causal Inference for Statistics, Social, and Biomedical Sciences: An Introduction. New York, NY: Cambridge University Press.

IPCC. 2018. "Summary for Policymakers." In: V. Masson-Delmotte, P. Zhai, H.-O. Pörtner, D. Roberts, J. Skea, P.R. Shukla, A. Pirani, W. Moufouma-Okia, C. Péan, R. Pidcock, S. Connors, J.B.R. Matthews, Y. Chen, X. Zhou, M.I. Gomis, E. Lonnoy, T. Maycock, M. Tignor, and T. Waterfield (eds), Global Warming of $1.5^{\circ} \mathrm{C}$. An IPCC Special Report on the Impacts of Global Warming of $1.5^{\circ} \mathrm{C}$ Above Pre-Industrial Levels and Related Global Greenhouse Gas Emission Pathways, in the Context of Strengthening the Global Response to the Threat of Climate Change, Sustainable Development, and Efforts to Eradicate Poverty (32 pp). Geneva, Switzerland: World Meteorological Organization.

Iyer, P., M. Bozzola, S. Hirsch, M. Meraner, and R. Finger. 2020. "Measuring Farmer Risk Preferences in Europe: A Systematic Review." Journal of Agricultural Economics 71(1): 3-26.

Jappelli, T., and L. Pistaferri. 2010. "The Consumption Response to Income Changes." Annual Review of Economics 2(1): 479-506.

Kazianga, H., and C. Udry. 2006. "Consumption Smoothing? Livestock, Insurance and Drought in Rural Burkina Faso." Journal of Development Economics 79(2): 413-446.

Kistner, E., O. Kellner, J. Andresen, D. Todey, and L. Morton. 2018. "Vulnerability of Specialty Crops to Short-Term Climatic Variability and Adaptation Strategies in the Midwestern USA." Climatic Change 146(1): 145-158.

Kuwayama, Y., A. Thompson, R. Bernknopf, B. Zaitchik, and P. Vail. 2019. "Estimating the Impact of Drought on Agriculture Using the U.S. Drought Monitor." American Journal of Agricultural Economics 101(1): 193-210.

Lee, H., J. Harwood, and A. Somwaru. 1997. "Implications of Disaster Assistance Reform for Non-Insured Crops." American Journal of Agricultural Economics 79(2): 419-429.

Lins, D., S. Gabriel, and S. Sonka. 1981. "An Analysis of the Risk Aversion of Farm Operators: An Asset Portfolio Approach.” Western Journal of Agricultural Economics 6(1): 15-29.

Malmendier, U., and S. Nagel. 2011. "Depression Babies: Do Macroeconomic Experiences Affect Risk Taking?” The Quarterly Journal of Economics 126(1): 373-416.

Medellín-Azuara, J., D. MacEwan, R. Howitt, D. Sumner, and J. Lund. 2016. "Economic Analysis of the 2016 Drought for California Agriculture.” Working Paper, Center for Watershed Sciences, University of California Davis, Davis, CA.

Morduch, J. 1995. "Income Smoothing and Consumption Smoothing." The Journal of Economic Perspectives 9(3): 103-114. 
National Agricultural Statistics Service. 2019a. 2017 Census of Agriculture, Specialty Crops. Washington, DC: United States Department of Agriculture. Available at: https://www.nass.usda.gov/Publications/ AgCensus/2017/Online_Resources/Specialty_Crops/SCROPS.pdf (accessed March 2019).

National Agricultural Statistics Service. 2019b. 2017 Census of Agriculture, State Data. Washington, DC: United States Department of Agriculture. Available at: https://www.nass.usda.gov/Publications/AgCensus/2017/ Full_Report/Volume_1,_Chapter_1_State_Level/Indiana/st18_1_0077_0077.pdf (accessed January 2020).

National Agricultural Statistics Service. 2019c. 2017 Census of Agriculture, State Profile. Washington, DC: United States Department of Agriculture. Available at: https://www.nass.usda.gov/Publications/ AgCensus/2017/Online_Resources/County_Profiles/index.php (accessed July 2020).

Ogurtsov, V., M.A.P.M.V. Asseldonk, and R.B.M. Huirne. 2008. "Assessing and Modelling Catastrophic Risk Perceptions and Attitudes in Agriculture: A Review." NJAS Wageningen Journal of Life Sciences 56 (1/2): 39-58.

Olen, B., and J. Wu. 2017. "Tracking the Evolution and Recent Development in Whole Farm Insurance Programs." Choices: The Magazine of Food, Farm and Resource Issues (Online) 32(3): 1-9.

Porter, C. 2012. "Shocks, Consumption and Income Diversification in Rural Ethiopia." The Journal of Development Studies 48(9): 1209-1222.

Pratt, J. 1964. "Risk Aversion in the Small and in the Large." Econometrica 32(1-2): 122-136.

Reibsame, W., S.A. Changnon, and T. Karl. 1991. Drought and Natural Resources Management in the United States: Impacts and Implications of the 1987-89 Drought. Westview Special Studies in Natural Resources and Energy Management. Boulder, CO: Westview Press.

Rosenzweig, M.R., and H.P. Binswanger. 1993. "Wealth, Weather Risk and the Composition and Profitability of Agricultural Investments." The Economic Journal 103(416): 56-78.

Shannon, H.D., and R.P. Motha. 2015. "Managing Weather and Climate Risks to Agriculture in North America, Central America and the Caribbean." Weather and Climate Extremes 10(Part A): 50-56.

Shields, D.A. 2017. Crop Insurance Covers Most Major Crops. Farm Credit Administration, USA. Available at: https://www.fca.gov/template-fca/download/EconomicReports/CropInsuranceCoversMostMajorCrops. pdf (accessed February 2019).

Smith, A.B. 2018. 2017 U.S. Billion-Dollar Weather and Climate Disasters: A Historic Year in Context. NOAA Climate.gov. Available at: https://www.climate.gov/news-features/blogs/beyond-data/2017-us-billion-dollar-weather-and-climate-disasters-historic-year (accessed February 2019).

Starmer, C. 2000. "Developments in Non-Expected Utility Theory: The Hunt for a Descriptive Theory of Choice Under Risk." Journal of Economic Literature 38(2): 332-382.

Torres, A., and M. Marshall. 2016. "Fruit and Vegetable Farmer Surveys: Characteristics of Indiana Vegetable Farming Operations." Purdue Extension Publication No. HO-270-W, Purdue University.

Townsend, R. 1994. "Risk and Insurance in Village India." Econometrica 62(3): 539.

Voiland, A. 2020. Derecho Flattens Iowa Corn. NASA Earth Observatory. Available at: https://earthobservatory.nasa.gov/images/147154/derecho-flattens-iowa-corn (accessed December 2020).

Walthall, C.L., J. Hatfield, P. Backlund, L. Lengnick, E. Marshall, M. Walsh, S. Adkins, M. Aillery, E.A. Ainsworth, C. Ammann, C.J. Anderson, I. Bartomeus, L.H. Baumgard, F. Booker, B. Bradley, D.M. Blumenthal, J. Bunce, K. Burkey, S.M. Dabney, J.A. Delgado, J. Dukes, A. Funk, K. Garrett, M. Glenn, D.A. Grantz, D. Goodrich, S. Hu, R.C. Izaurralde, R.A.C. Jones, S-H. Kim, A.D.B. Leaky, K. Lewers, T.L. Mader, A. McClung, J. Morgan, D.J. Muth, M. Nearing, D.M. Oosterhuis, D. Ort, C. Parmesan, W.T. Pettigrew, W. Polley, R. Rader, C. Rice, M. Rivington, E. Rosskopf, W.A. Salas, L.E. Sollenberger, R. Srygley, C. Stöckle, E.S. Takle, D. Timlin, J.W. White, R. Winfree, L. Wright-Morton, and L.H. Ziska. 2013. "Climate Change and Agriculture in the United States: Effects and Adaptation." Geological and Atmospheric Sciences Reports No. 1.

Westhoff, P., S. Meyer, J. Binfield, and S. Gerlt. 2020. "Early Estimates of the Impacts of COVID-19 on U.S. Agricultural Commodity Markets, Farm Income and Government Outlays." FAPRI-MU Report No. 02-20, University of Missouri.

Zhao, S., and C. Yue. 2020. "Risk Preferences of Commodity Crop Producers and Specialty Crop Producers: An Application of Prospect Theory." Agricultural Economics 51(3): 359-372. 


\section{Appendix}

Table A1. Indiana Specialty Crop Producers' Demographics

\begin{tabular}{|c|c|c|c|}
\hline & Mean & St. Dev. & 2017 Census mean \\
\hline Respondent age $(n=63)$ & 57.79 & 15.03 & 55.5 \\
\hline Respondent spouse age $(n=47)$ & 55.19 & 12.22 & - \\
\hline Members Living in Household $(n=64)$ & 3 & 1.4 & 3.6 \\
\hline Farm assets $(\$)(n=56)$ & $2,424,292$ & $5,268,637$ & $1,900,876$ \\
\hline Household monthly income $(\$)(n=78)$ & $6,055.29$ & $5,593.37$ & - \\
\hline \multirow[t]{2}{*}{ Household assets $(\$)(n=55)$} & 449,419 & 486,404 & - \\
\hline & Frequency & Percentage & 2017 Census (\%) \\
\hline \multicolumn{4}{|l|}{ Gender $(n=82)$} \\
\hline Female & 18 & 22.0 & 33.0 \\
\hline Male & 64 & 78.0 & 67.0 \\
\hline \multicolumn{4}{|l|}{ Married $(n=64)$} \\
\hline No & 16 & 25.0 & - \\
\hline Yes & 48 & 75.0 & - \\
\hline \multicolumn{4}{|l|}{ Respondent race $(n=62)$} \\
\hline American Indian & 1 & 1.6 & 0.00 \\
\hline Other & 1 & 1.6 & 0.70 \\
\hline White & 60 & 96.8 & 99.30 \\
\hline \multicolumn{4}{|l|}{ Respondent's spouse race $(n=43)$} \\
\hline White & 43 & 100 & - \\
\hline \multicolumn{4}{|l|}{ Respondent education $(n=63)$} \\
\hline High school or less & 16 & 25.4 & - \\
\hline Above high school & 47 & 74.6 & - \\
\hline \multicolumn{4}{|l|}{ Respondent's spouse education $(n=47)$} \\
\hline High school or less & 8 & 17 & - \\
\hline Above high school & 39 & 83 & - \\
\hline \multicolumn{4}{|c|}{ Respondent occupation-majority time $(n=62)$} \\
\hline Not in workforce & 6 & 9.7 & 43.1 \\
\hline Work other than farming & 15 & 24.2 & \\
\hline Farming & 41 & 66.1 & 56.9 \\
\hline \multicolumn{4}{|c|}{ Respondent's spouse occupation-majority time $(n=42)$} \\
\hline Not in workforce & 8 & 19.0 & - \\
\hline Work other than farming & 25 & 59.5 & - \\
\hline Farming & 9 & 21.4 & - \\
\hline
\end{tabular}

Notes: Summary statistics are based on the authors' survey of Indiana specialty crop producers. Relevant summary statistics for all Indiana agricultural producers are provided in the fourth column (subject to availability), using the USDA 2017 Census of Agriculture, that is, 2017 Census Volume 1, Chapter 1: Indiana, Table 77. The census statistic for "Members Living in Household" is calculated using the formula: (The number of persons living in producers' household)/ (total farms). The census statistic for the farm assets value is based on the estimated market value of land, buildings, all machinery, and equipment in Table 77. The census only reports the sex of producers when there are four producers in an operation. The term "majority time" means $50 \%$ or more time spent at an occupation. The census statistic for producer occupation is based on "Days of work off farm" in Table 77. 
Table A2. Indiana Specialty Crop Producers Farm Operation Statistics

\begin{tabular}{|c|c|c|c|}
\hline & Mean & St. Dev. & 2017 Census mean \\
\hline Percent of farm owned $(n=63)$ & 70.87 & 37.2 & See notes \\
\hline Acres of vegetables and melons $(n=84)$ & 56.93 & 440.95 & 47.42 \\
\hline Acres of fruits, nuts, and berries $(n=84)$ & 7.73 & 36.25 & 2.79 \\
\hline \multirow[t]{2}{*}{ Acres of other crops $(n=84)$} & 639.68 & 1,454 & 212.81 \\
\hline & Frequency & Percentage & 2017 Census (\%) \\
\hline \multicolumn{4}{|l|}{ Farm operation legal status } \\
\hline \multicolumn{4}{|l|}{ Family or individual operation $(n=62)$} \\
\hline (Yes/No) & $(34 / 28)$ & $(54.8 / 45.2)$ & 85.04 \\
\hline \multicolumn{4}{|l|}{ Legal partnership $(n=62)$} \\
\hline (Yes/No) & $(13 / 49)$ & $(21.0 / 79.0)$ & 0.06 \\
\hline \multicolumn{4}{|l|}{ C- or S-corporation $(n=62)$} \\
\hline (Yes/No) & $(19 / 43)$ & $(30.6 / 69.4)$ & 0.07 \\
\hline \multicolumn{4}{|l|}{ Trust or cooperative $(n=62)$} \\
\hline (Yes/No) & $(2 / 60)$ & $(3.2 / 96.8)$ & 0.02 \\
\hline \multicolumn{4}{|l|}{ Available financial instrument to run farm } \\
\hline \multicolumn{4}{|l|}{ Insurance $(n=83)$} \\
\hline (Yes/No) & $(55 / 28)$ & $(66.3 / 33.7)$ & \\
\hline \multicolumn{4}{|l|}{ Government loan $(n=83)$} \\
\hline (Yes/No) & $(26 / 57)$ & $(31.3 / 68.7)$ & \\
\hline \multicolumn{4}{|l|}{ Bank loan $(n=83)$} \\
\hline (Yes/No) & $(53 / 30)$ & $(63.9 / 36.1)$ & \\
\hline \multicolumn{4}{|l|}{ Relatives loan $(n=83)$} \\
\hline (Yes/No) & $(9 / 74)$ & $(10.8 / 89.2)$ & \\
\hline \multicolumn{4}{|l|}{ Personal savings $(n=83)$} \\
\hline (Yes/No) & $(53 / 30)$ & $(63.9 / 36.1)$ & \\
\hline \multicolumn{4}{|l|}{ Supplier credit $(n=83)$} \\
\hline (Yes/No) & $(36 / 47)$ & $(43.4 / 56.6)$ & \\
\hline \multicolumn{4}{|l|}{ Credit card $(n=83)$} \\
\hline (Yes/No) & $(46 / 37)$ & $(55.4 / 44.6)$ & \\
\hline \multicolumn{4}{|l|}{ None available $(n=83)$} \\
\hline (Yes/No) & $(7 / 76)$ & $(8.4 / 91.6)$ & \\
\hline
\end{tabular}

Notes: Summary statistics are based on the authors' survey of Indiana specialty crop producers. Relevant summary statistics for all Indiana agricultural producers are provided in the fourth column (subject to availability), using the USDA 2017 Census of Agriculture, that is, 2017 Census Volume 1, Chapter 1: Indiana, Table 77. In our survey, full owners represent $55.55 \%$ of all producers, and this percentage is 67 in the 2017 census. In calculating average acres per farm operation in the census, we consider only the irrigated acres and farms. For "other crops" we consider corn, corn for silage, soybean, wheat, and forage land for hay and grass. In the authors' survey, producers were allowed to select multiple categories of farm legal status; hence, the percentages may not be directly comparable with the census percentages. 
Table A3. Treatment/Control Balance-Household Income and Consumption Expenses Before the Income Shock

\begin{tabular}{|c|c|c|c|c|}
\hline & \multicolumn{4}{|c|}{ Regression sample $(N=47)$} \\
\hline & $\begin{array}{l}\text { Treatment } \\
\text { mean }(\$)\end{array}$ & $\begin{array}{l}\text { Control } \\
\text { mean }(\$)\end{array}$ & $\begin{array}{l}\text { Norm. } \\
\text { diff. score }\end{array}$ & $\begin{array}{c}\text { Mean share } \\
\text { of income }\end{array}$ \\
\hline \multicolumn{5}{|l|}{ Monthly } \\
\hline Income & $5,827.18$ & $5,422.37$ & 0.09 & 1.00 \\
\hline Health & 698.61 & 561.58 & 0.26 & 0.15 \\
\hline Rent & 53.57 & 41.32 & 0.09 & 0.01 \\
\hline Household furnishings & 68.79 & 70.79 & 0.02 & 0.02 \\
\hline Commitments category & 820.96 & 673.68 & 0.25 & 0.18 \\
\hline Food & 569.68 & 533.84 & 0.10 & 0.12 \\
\hline Education & 40.61 & 130.26 & 0.34 & 0.02 \\
\hline $\begin{array}{l}\text { Transportation (including } \\
\text { gas and maintenance) }\end{array}$ & 420.89 & 539.32 & 0.31 & 0.11 \\
\hline Entertainment & 124.71 & 183.89 & 0.34 & 0.03 \\
\hline Clothing and personal care & 117.61 & 142.05 & 0.18 & 0.03 \\
\hline Utilities & 329.46 & 399.84 & 0.21 & 0.09 \\
\hline Miscellaneous & $1,312.79$ & $1,260.63$ & 0.04 & 0.25 \\
\hline Adjustables category & $2,915.75$ & $3,189.84$ & 0.14 & 0.64 \\
\hline All consumption expenses & $3,672.43$ & $3,864.21$ & 0.08 & 0.80 \\
\hline Total observations & 28 & 19 & & 47 \\
\hline All variables (average) & - & - & 0.17 & - \\
\hline
\end{tabular}

Notes: We follow the definition of Chetty and Szeidl (2007) for "commitments" and "adjustables" categories, and follow their Table 1 in identifying which expenses belong to each commitments and adjustables category. Expenses for health, rent, and furnishings belong to the commitments category, and the rest of the expenses belongs to the adjustables category. Since our definition of transportation includes gas and maintenance, and clothing includes personal care items, we assign these to the adjustables category. Normalized difference scores are calculated based on the Imbens and Rubin (2015) method. As a rule of thumb, a score above 0.25 or 0.5 signifies imbalance in treatment arms. The fifth column (mean share of income) pools both treatment and control households. 
Table A4. Indiana Specialty Crop Producers' Resiliency Against Natural Disasters

\begin{tabular}{|c|c|c|}
\hline & Mean & St. Dev. \\
\hline \multirow[t]{2}{*}{ Insured share of planted acres $(n=73)$} & 0.42 & 0.47 \\
\hline & Frequency & Percentage \\
\hline $\begin{array}{l}\text { Do you engage in farm financial planning for worst times like losses due } \\
\text { to flood or drought? (Yes/No) }(n=83)\end{array}$ & $(44 / 39)$ & $(53.0 / 47.0)$ \\
\hline Has an extreme event ever affected your farm? (Yes/No) $(n=84)$ & $(67 / 17)$ & $(79.8 / 20.2)$ \\
\hline \multicolumn{3}{|l|}{ Financial instrument you would use after farm losses due to disaster } \\
\hline \multicolumn{3}{|l|}{ Insurance $(n=83)$} \\
\hline (Yes/No) & $(48 / 35)$ & $(57.8 / 42.2)$ \\
\hline \multicolumn{3}{|l|}{ Government loan $(n=83)$} \\
\hline (Yes/No) & $(27 / 56)$ & $(32.5 / 67.5)$ \\
\hline \multicolumn{3}{|l|}{ Bank loan $(n=83)$} \\
\hline$(\mathrm{Yes} / \mathrm{No})$ & $(47 / 36)$ & $(56.6 / 43.4)$ \\
\hline \multicolumn{3}{|l|}{ Relatives loan $(n=83)$} \\
\hline (Yes/No) & $(10 / 73)$ & $(12.0 / 88.0)$ \\
\hline \multicolumn{3}{|l|}{ Personal savings $(n=83)$} \\
\hline (Yes/No) & $(45 / 38)$ & $(54.2 / 45.8)$ \\
\hline \multicolumn{3}{|l|}{ Supplier credit $(n=83)$} \\
\hline (Yes/No) & $(21 / 62)$ & $(25.3 / 74.7)$ \\
\hline \multicolumn{3}{|l|}{ Credit card $(n=83)$} \\
\hline (Yes/No) & $(19 / 64)$ & $(22.9 / 77.1)$ \\
\hline \multicolumn{3}{|l|}{ If you needed $\$ 100,000$ loan, who would you ask for it? } \\
\hline \multicolumn{3}{|l|}{ Family $(n=63)$} \\
\hline (Yes/No) & $(9 / 54)$ & $(14.3 / 85.7)$ \\
\hline \multicolumn{3}{|l|}{ Relatives $(n=63)$} \\
\hline (Yes/No) & $(4 / 59)$ & $(6.3 / 93.7)$ \\
\hline \multicolumn{3}{|l|}{ Bank $(n=63)$} \\
\hline (Yes/No) & $(53 / 10)$ & $(84.1 / 15.9)$ \\
\hline \multicolumn{3}{|l|}{ Farm service agency $(n=63)$} \\
\hline (Yes/No) & $(23 / 40)$ & $(36.5 / 63.5)$ \\
\hline \multicolumn{3}{|l|}{ Climate change perception question and statements } \\
\hline $\begin{array}{l}\text { Is climate change important to your farm management } \\
\text { decisions? (Yes/No) }(n=84)\end{array}$ & $(46 / 38)$ & $(54.8 / 45.2)$ \\
\hline \multicolumn{3}{|c|}{ Weather and climate change presents more risks than benefits to Indiana agriculture } \\
\hline Strongly disagree & 5 & 6.0 \\
\hline Somewhat disagree & 8 & 9.5 \\
\hline
\end{tabular}


Table A4. (Continued.)

\begin{tabular}{llc}
\hline & Mean & St. Dev. \\
\hline Neither agree nor disagree & 20 & 23.8 \\
\hline Somewhat agree & 26 & 31.0 \\
\hline Strongly agree & 25 & 29.8 \\
\hline I am worried about weather and climate change & & 9.5 \\
\hline Strongly disagree & 8 & 15.5 \\
\hline Somewhat disagree & 13 & 17.9 \\
\hline Neither agree nor disagree & 15 & 29.8 \\
\hline Somewhat agree & 25 & 27.4 \\
\hline Strongly agree & 23 & 23 \\
\hline
\end{tabular}

Notes: Summary statistics are based on the authors' survey of Indiana specialty crop producers.

Cite this article: Wahdat AZ, Gunderson MA, Lusk JL (2021). Farm Producers' Household Consumption and Individual Risk Behavior after Natural Disasters. Agricultural and Resource Economics Review 50, 127-149. https://doi.org/10.1017/age.2021.2 